\title{
FORMATION OF ETHNIC CONSCIOUSNESS OF THE FUTURE PEDAGOGUE IN THE CONDITIONS OF THE EUROPEAN EDUCATIONAL SPACE
}

\author{
MARYNA VASYLYK
}

\begin{abstract}
The article is devoted to modern approaches of formation of ethnic consciousness of future teachers of primary school in the conditions of the multicultural society and their education as citizens of Europe. Multicultural competence is a factor of a successful professional activity. In the article, the author analyzed the problem of forming of future specialists' multicultural competence in connection with the globalization processes and integration of Ukrainian higher education in European educational community. The research stresses that formation of students' outlook, their value orientations, modern social and humanistic thinking in an educational process are important. It is emphasized that the multiculturalness must become an integral part of every national educational system. The multiculturalness is a key principle of making totally new educational system of Ukraine. Respect and acceptance of cultural variety in the society coexistence of dialogues without loss of the national and cultural identity of the representatives of the society leads to its spiritual and cultural enriching.

The article is an author's translation of the text published in the Journal of the National Academy of the State Border Guard Service of Ukraine, series: Pedagogics, 5 (2016) (in Ukrainian). Keywords: pedagogical education, ethnic consciousness, teacher, multicultural education, European educational space, European identity.
\end{abstract}

\section{INTRODUCTION}

Modern pedagogical education of Ukraine, as a component of the European educational space, is designed to form a specialist (Bachelor / Master) who has a solid scientific knowledge, the ability to transfer it to the subjects of the pedagogical process and is capable of active and effective livelihoods in a multinational and multicultural environment, has a developed sense of understanding and respect for other cultures, is able to live in peace and harmony with people of different nationalities, races, beliefs. Such a teacher, being a citizen of Europe and adhering to universal human values, at the same time remains the bearer of his own ethnic culture, able to provide students with the culture of different peoples living in one country and on one continent (Europe), creating the conditions for the emergence of a sense of trust and solidarity between them, ability to interact. Meanwhile, the analysis of the activity of the pedagogical universities of Ukraine gives grounds to assert that in the training of future teachers for the formation of ethnic consciousness as a factor in preserving their ethno-cultural identity 
and the ability to provide multicultural education and upbringing so far, despite the challenges of the time, insufficient attention is paid in scientific literature $[2 ; 3 ; 8 ; 9]$.

The paper examined the latest researches and publications in which the solution of this problem was initiated and which the author relies on. Actually, the researchers of this problem O. Budnyk, T. Blyznyuk, L. Golyk, T. Klinchenko, M. Krasovytsky, K. Levchenko, S. Martynenko, L. Khomych, L. Horuzha and others considered different aspects of preparing future teachers, for the professional activities in the multicultural society.

The article contains materials that were published by the author in Ukrainian in the "Bulletin of the National Academy of the State Border Guard Service of Ukraine", series: Pedagogics, 5 (2016).

\section{ANALYSIS AND DiscusSiON}

Today, in conditions of the development of the Ukrainian state and the reformation of its educational system, deeply wise, very prophesied words of the titan of thought and work of Ivan Franko "School is standing by a teacher" become especially relevant. But, due to the current situation in Ukraine, we could change this idea a bit and proclaim: "The state is a teacher". It was such a teacher's role that the German Chancellor Bismarck was well aware of at the time, saying: "Give me two thousand good teachers and I will make a new Germany in a few years". Since we also are striving to build new Ukraine, we must give a priority to the preparation of nationally conscious pedagogical staff.

Retrospective analysis shows that with the proclamation of Ukraine's independence, certain steps have been taken in this direction. The basic legislative field of the education sector was created, the legal and regulatory framework for the development of the national education system was developed, in particular, the Laws "On Education", "On Pre-school Education", "On Extracurricular Education", "On Vocational Education", "On Higher Education", The National Doctrine of the Development of Education of Ukraine in the XXI Century, the State Program "Teacher" was approved.

We emphasize that formation of the national education system is undergoing a significant change in the spiritual space of society that requires sower "good, wise, eternal" rethinks and refines own ideological position, and makes certain prospects in the goals, objectives and content of educational space.

In the new philosophy of education, the student (pupil) is a socio-cultural personality that is constantly evolving along with socio-cultural space. Student (pupil) - this is the result and the process of development of the socio-cultural system. Therefore, the main feature of modern pedagogical thinking is not only the adoption of certain provisions and ideas, but primarily on the basis of designing integrated educational models that reflect the public as a single system, and purely psychological and pedagogical views and beliefs. The foundation of these models is the modern philosophy of education, that is, socio-philosophical approaches to the student (pupil) [3;4].

Since a student (pupil) has become the center of attention, then the important function of the teacher is the ability to assist in the effective and creative development of information, in the development of its critical thinking. In the world educational environment, in connection with the change in the paradigm of pedagogical functions, the term "facilitator" means the one who facilitates learning, promotes it, helps to learn. It should be emphasized that, subject to the use of state-of-the-art computer systems, high telecommunication technologies, which, without any doubt, stimulates the effectiveness of the educational process, yet nothing and no one can completely supersede and replace the art of direct pedagogical dialogue "teacher-student". Therefore, it is especially important to train high-professional pedagogical and scientific and pedagogical workers who meet the integration criteria "pedagogical skills + art of communication + the latest technologies".

Equally important is the relationship between man and the world. The fact is that the modern world and the future of the world differ considerably from one another. This is due not only to geopolitical changes. Along with the creation of the best prerequisites for personalization of the individual, the tendency to awareness of the integrity of the world, its interconnectedness is increasing. The state is modern, and even more, the future, cannot be separated, closed, so that it has no permanent 
connection with another part of the world. And it requires the preparation of such a person, a citizen, a person who would be able to interact organically with humanity, with citizens of other countries and in the field of production, in the sphere of political relations, and in the spiritual sphere, at the individual level. It requires formation of a specialist who would understand the need for such communication, as well as capable of such communication. That is the question of studying as many cultural models and images of culture as possible with the "pictures of the world" - all of its diversity, without absolute or accepting the ideal of a particular culture (moral and ethical, religious system, social order), students' beliefs in the relativity of any value hierarchy, any representation of the necessary, of the true, etc.; formation of tolerance and tolerance in relation to foreign cultural existence as an instrument of interethnic communication, belief in the inadmissibility of racist, chauvinistic and nationalist manifestations in any sphere of cultural life; study of democratic values, which is the only possible system of values, the guarantor of the preservation of diversity in the interests of equality and free development of all cultures.

"Globalization is inseparable from ethnization. Ethnic education is based on a thorough coverage of the background meanings of the various branches of scientific knowledge for the development of ethnic culture, literature, art, world culture achievements, and education on life examples of famous people, representatives of one's own people... Multicultural education is a way of thinking of a modern man, based on the ideas of freedom, tolerance, justice, equality and peace" [13, p. 94-95].

In this context, the problem of patriotism, ethnic consciousness and self-consciousness becomes a matter of special urgency. Often contrasted: patriotism vs non-patriotism. Now and in the future, in conditions when the state is open and must act in connections with other countries, and in the educational process it is necessary to prepare a person for being a patriot of one's homeland and at the same time a citizen of Europe, the world. Ukrainian researchers point out that multicultural education and upbringing should not be a national one, but should be considered together as part of a single process. In their opinion, such a combination will contribute to a deep assimilation and understanding of both national and universal human moral values. At the same time, it should be born in mind that each person may have different feelings about belonging or not belonging to a particular ethnic community. This is called the ethnic competence of the individual. There is also ethnocultural competence of a person - this is the ability of a person to freely navigate the world of values of the culture of own ethnic group, to freely understand the language, "codes", "ciphers" of this ethnic culture and to freely create this language [6].

Ethnic competence is closely linked to ethnic consciousness: these two categories are in close proportional proportions: the higher the ethnic competence of the individual, the higher the level of its ethnic consciousness.

Ethnic identity of a person is a set of knowledge and ideas about culture, traditions, ideals, values of one's ethnic group, as well as awareness of a member of an ethnic group and of the place of its people among other peoples.

Ethnic (national) self-consciousness of individuals has different levels:

1) persons of low ethnic (national) awareness, almost or completely assimilated by a stranger (dominant, imperial) ethnos, are not only indifferent, but often hostile to their ethnic group; they do not add energy to their people, on the contrary - act as centrifugal forces of disruption and the collapse of ethnic integrity;

2) persons with a moderate national consciousness also give little benefit to state creation, because their national consciousness is not so strong that it actively manifests it;

3) a high level of national consciousness (maximal ethnicity) unites people who are actively involved in the activities of their ethnic group in securing its political, economic, social and other interests.

The ethnic identity of the person, as well as the collective ethnic consciousness, preserves the memory of the old kinds of occupations, sanctified and glorified in the myths, folklore of the people, that is, preserves and reproduces culture in the forms of ethnic existence. Ethnic self-awareness can realize oneself in the acts of cultural creativity, which they call to call "cultural nationalism". 
Thus, it is a question of preparing a teacher with a high level of ethnic consciousness, capable of interacting with the multicultural world and at the same time retaining their ethnic identity, their patriotic feelings and beliefs.

It is impossible to raise education without paying tribute to its key figure - the teacher. Teacher is the main factor in reforming education. He must not only have command of the subject, but also be able to navigate the relevant field of knowledge, integrate within the framework of related disciplines, build curricula, and form students' self-education skills. All this is about the teacher who is a creative personality. A teacher of such level of professionalism sees a high personal meaning of everything that is happening in the process of professional activity. Communicating with children is a personal significant value, the teacher has the breadth of enthusiasm, empathy, professional intuition, the will and purpose in achieving goals. Therefore, the teacher's training must first of all ensure the growth of his creative personality.

Particular attention at the present stage of the development of pedagogical education deserves the problem of training teachers of dual specialties and specializations. You can cite many arguments for and against. But the truth, obviously, is on the side of those who take into account the real situation of the school and relies on domestic and foreign experiences.

Obviously, such a combination is necessary, but it needs to be carefully and scientifically substantiated.

Experience has shown that, in the first place, are those who are close to the content of the specialty education, that is, those that complement each other, may be combined. Pedagogical specialties are introduced on the same principles, which include the preparation of teachers for the teaching educational subjects of the variable component of the curriculum and the conduct of extracurricular and extracurricular work.

It should be immediately warned that the concept of "pedagogical specialization" in this sense is somewhat different from its generally accepted interpretation as an in-depth professional training within the given specialty. The content of education in pedagogical specialization should also be normalized, that is to enter the industry standard as its component and facilitate the formation of a teacher capable of successfully self-asserting in the European educational space, based on the principles of harmonious own ethnic culture and multicultural education, aimed at the formation of a European identity.

\section{CONCLUSIONS}

Based on the investigation the process of future primary school teachers preparation the methodological foundations concerning the formation of their ethnic consciousness in the context of modern European requirements have been revealed.

Students' readiness for professional activity in the ethno-cultural environment is manifested in the ability to apply professional knowledge and skills in a particular ethnic surrounding. Pedagogical innovations in education serve as a means of forming students' abilities to direct social contacts in an external environment, to critically evaluate negative trends in the society, to respect representatives of other social spheres and cultures.

The analysis of the activity of Ukrainian pedagogical institutions in the context of the Bologna process [5] suggests that they actually have the necessary opportunities for the formation of a patriot of the native state and, at the same time, a citizen of Europe with a high level of ethnic self-awareness and collective ethnic consciousness. 


\section{REFERENCES}

[1] Maievska L.M. Model of preparation of the future teacher for ethnocultural education of junior schoolchildren. Pedagogy of Higher and Secondary Education, 28 (2010), 334-342. Available at: http://eprints.zu.edu.ua/4322/ (in Ukrainian)

[2] Soroka M.V. Polycultural education is a requirement of today. Pedagogical education: theory and practice. Psychology. Pedagogy, 9 (2008), 53-56. (in Ukrainian)

[3] Tishulina S.G. Polycultural education in the system of training future teachers. MSTU, 9 (4) (2006), 573575. Available at: http://vestnik.mstu.edu.ru/v09_4_n24/articles/06_tishul.pdf (in Russian)

[4] Cherepanova S.O. Multicultural foundations of Ukrainian higher education XIV-XVIII centuries, the philosophical and humanistic aspect. Visnyk of the Lviv University. Series Pedagogics, 14 (1999), 56-65. (in Ukrainian)

[5] Kremen V.G. (Ed.) Higher Education of Ukraine and Bologna Process. Bohdan Publishing House, Ternopil, 2004. (in Ukrainian)

[6] Maievska L.M. Features of formation of ethnocultural competence of the future teacher in the context of globalization shifts. Humanitarny Visnyk Pereyaslav-Hmelnytskogo Derzhavnogo Pedagogichnogo Universytetu imeni Hryhoriya Skovorody, (2006), 303-309. Available at: http://eprints.zu.edu.ua/3554/ (in Ukrainian)

[7] Atroshchenko T. Development of the culture of interethnic communication in the student collective. The Scientific Issues of Ternopil Volodymyr Hnatiuk National Pedagogical University. Series: pedagogy, 6 (1999), 92-95. (in Ukrainian)

[8] Khotinets V. Y. Formation of ethnic identity of students in the process of learning in High School. Voprosy Psychologii, 3 (1998), 31-42. (in Russian)

[9] Sydorchuk N.G. Professional and pedagogical preparation of university students in the context of a single European educational space: historical and pedagogical aspect. Zhytomyr Ivan Franko State University, Zhytomyr, 2014. (in Ukrainian)

[10] Vorotnyak L.I. The Peculiarities of Master's Multicultural Competence Formation at Pedagogical Higher Educational Establishments. Zhytomyr Ivan Franko State University Journal. Pedagogical sciences, 39 (2008), 105-109. (in Ukrainian)

[11] Olishevych V. Multiculturalism through the prism of the pedagogical science. Current issues of education and science. Collected articles Materials of III international scientific and practical conference (November 10-11, 2015, Kharkiv, Ukraine). National Academy of National Guard of Ukraine. Khohokz, Kharkiv, 2015, 151-154. (in Ukrainian)

[12] Rymarenko Yu. (Ed.) Small encyclopedia of ethno-state studies. Dovira, Geneza, Kyiv, 1996. (in Ukrainian)

[13] Stępnik A., Budnyk O., Blyznyuk T., Mazur P. Regional and multicultural education in Poland and Ukraine. Journal of Vasyl Stefanyk Precarpathian National University, 4 (1) (2017), 87-96. doi: 10.15330/jpnu.4.1.87-96

Address: Maryna Vasylyk, Vasyl Stefanyk Precarpathian National University, 57, Shevchenko Str., IvanoFrankivsk, 76018, Ukraine.

E-mail: vasilikmarina6@gmail.com

Received: 03.12.2018; revised: 25.01.2019.

Василик Марина. Формування етнічної свідомості майбутнього педагога в умовах європейського освітнього простору. Журнал Прикарпатського університету імені Василя Стефаника, 6 (1) (2019), 155-160. 
У статті актуалізуються сучасні дослідження формування полікультурної компетентності у майбутніх фахівців у зв'язку з глобалізаційними процесами та інтегруванням вищої освіти України до європейського освітнього простору. Важдивим $є$ формування у студентів світогдяду, їх ціннісних орієнтацій, сучасного соціально-гуманістичного мислення в навчальному процесі закладу вищої освіти. Наголошено, що полікультурність слугує невід'ємною частиною кожної національної системи освіти. Полікультурність є кдючовим принципом формування абсолютно нової освітньої системи України; адже повага і прийняття культурного різноманіття в суспільстві, співіснування діалогів без втрати національно-культурної ідентичності представників суспільства призводять до його духовного і культурного збагачення.

Кдючові слова: педагогічна освіта, етнічна свідомість, учитель, полікультурна освіта, європейський освітній простір, європейська ідентичність. 